\title{
Social Conflict In Contestation Of Indonesia Election
}

\author{
Agus Machfud Fauzi ${ }^{1 *}$, Moh Mudzakkir ${ }^{2}$, Mohamed Omar Abdulrahim ${ }^{3}$ \\ ${ }^{1}$ Department of Social Science, Faculty of Social Science and Law, Universitas Negeri \\ Surabaya, Surabaya, Indonesia \\ Jalan Ketintang Surabaya, Indonesia \\ Email: agusmfauzi@unesa.ac.id \\ ${ }^{2}$ Centre for Policy Research \& International Studies (CenPRIS), Universiti Sains \\ Malaysia, Penang, Malaysia \\ Email: mudzakkir@student.usm.my \\ ${ }^{3}$ Department of Accounting, Faculty of Economics and Political Science, \\ Misurata University \\ Misrata City, Misrata, Libya \\ Email: m.abdulrahim@misuratau.edu.ly
}

\begin{abstract}
The background of this research is the conflict began with an inharmony between political party leaders and legislators, especially those who have become legislative members and intend to advance again as legislative candidates from the same party. It aims to provide solutions for political parties in the election nomination. It reveals conflict in the preparation of candidates in the elections of 2019. Researchers collect data from political party information and media coverage by comparing news. The method is qualitative with analysis using Paul Conn's conflict structure theory to produce alternative solutions. The results is a difference in expectations and designs between political party leaders and incumbent legislators, according to political party leaders that legislative incumbents need to have an evaluation so they are displaced from candidates for those who were not optimally fighting for political parties, different perspectives of incumbent legislators because they feel have struggled be serious and prepare for second (more) contestation. The legislative incumbent who should be eligible to advance back from the same electoral district then tries to find a new path by advancing again as a legislative candidate by using other political parties. The Conclusion is shifting legislative candidates and changes in the acquisition of election results show the dynamics of political party conflict affect the outcome.
\end{abstract}

Keywords: Politic, conflict, election, candidate, incumbent 


\begin{abstract}
Abstrak
Latar belakang dari penelitian ini adalah konflik, dimulai dengan ketidakharmonisan antara pemimpin partai politik dan legislator, terutama yang telah menjadi anggota legislatif, dan berniat untuk maju lagi sebagai kandidat legislatif dari partai yang sama. Penelitian ini bertujuan untuk memberikan solusi bagi partai politik dalam nominasi pemilu. Hal ini mengungkapkan konflik dalam persiapan kandidat dalam pemilihan 2019. Para peneliti mengumpulkan data dari informasi partai politik dan liputan media dengan membandingkan berita. Metode ini kualitatif dengan analisis menggunakan teori struktur konflik Paul Conn untuk menghasilkan solusi alternatif. Hasilnya adalah perbedaan dalam harapan dan desain antara pemimpin partai politik dan legislator yang menjabat, menurut para pemimpin partai politik bahwa petahana legislatif perlu melakukan evaluasi sehingga mereka dipindahkan dari kandidat untuk mereka yang tidak secara optimal memperjuangkan partai politik, perspektif berbeda dari legislator petahana karena mereka merasa telah berjuang menjadi serius dan mempersiapkan untuk kontes kedua (lebih). Legislatif petahana yang memenuhi syarat untuk maju kembali dari daerah pemilihan yang sama, kemudian berusaha untuk menemukan jalan baru dengan maju lagi sebagai calon legislatif dengan menggunakan partai politik berbeda. Kesimpulannya adalah menggeser kandidat legislatif menghadirkan perubahan dalam perolehan hasil pemilu, ini menunjukkan dinamika konflik partai politik berpengaruh terhadap hasil pemilu.
\end{abstract}

Kata kunci: politik, konflik, pemilu, kandidat, petahana 


\section{INTRODUCTION}

Society in state life is often hit by conflicts or differences in perspective on things. There are political conflicts and social conflicts that come with life, both of which grow more in developing societies. Political conflicts usually occur because of differences in political interests that can not be found a solution between the parties concerned, while social conflicts occur due to scrambling economic and political resources, then coupled with differences in social ornaments such as religion (including ethnicity) as often occurs in countries developing (Hidayat 2017; Fauzi, Sudrajat 2018).

In social conflicts as happened in the Ambon, Poso, Sampit until the current conflict about the Lampung and the Sumbawa. At first glance, the conflict occurs naturally in the middle of society, but actually, it starts from economic inequality, while religious differences appear to be the main issue (Muzaki 2018). Settlement of social conflicts by bringing together groups in conflict with an awareness of the long-term danger of conflict so that they are aware of the negative social conflict. It's easier to resolve than political conflicts it all people are aware of the causes of conflict, different political conflicts are usually more difficult because there is political interest.

Political conflict in the 2019 election occurred between the parties involved in the election contestation. Political parties are the first parties involved in the 2019 election conflict. Legislative candidates (DPR) and senate candidates (DPD or Regional Representative Council) are the second conflicting parties. The parties have an interest in winning the process of candidacy, although on the other hand they also play internal politics in political parties. The election of political party coalitions in response to nationality sometimes results in political conflict (Romli 2017).

The election organizer symbolized by the General Election Commission (KPU) and the Election Supervisory Body (BAWASLU) are parties that must be prepared to receive complaints from election participants. Some of them complained because they felt unfair enforcement by the election organizers which resulted in defeat in the election battle process. Commissioner of Election organizers must not be trapped by political party games carrying political 
identities, both participants have similarities in ethnicity, religion, race and among groups (Fuad 2014).

Politicians often get conflict tests in supporting and raising political parties. Some politicians in Indonesia have not been able to be consistent in living and developing in one political party. The phenomenon of the displacement of new political parties from political parties that have been raising during this time is common in the world of politicians. Those who feel threatened related to legislative nominations, immediately change political parties. The political party institutions entered did not feel any burden on the behavior of jumping politicians.

Legislative candidates have the target of winning the election battle so that they are elected and appointed as legislators. Political parties have an interest in increasing the number of legislators to convey the aspirations of the people who are stronger in bargaining their positions on government power. These initial goals often clash with the interest of politicians pragmatism, this makes the conflict in political parties does not build the greatness of the institution, instead, it makes the decline of the acquisition of political parties (Kamarudin 2013).

Good intentions are sometimes interpreted differently by someone who disagrees. Desire and hope to achieve both targets, it is necessary to struggle, in which often conflicts of interest arise, this is because there are different interests of fellow legislative candidates and political party officials. As long as pragmatism does not dominate, it does not affect the reduced legislative seats due to political parties.

The difference between this research and previous research is that this research shows the conflicting process of the legislative contestation, While Romli's research explains that internal party conflicts are caused by the attitude of coalition and opposition of political parties, while Fuad's research emphasizes that differences in people 's choice of candidates are different, between presidential election, local elections, in contrast to the legislative elections. The difference in this research enriches the treasury theory of conflict in the nomination of elections.

\section{METHODS}

Research on political party conflicts in this contest uses qualitative research methods, namely research that intends to understand the phenomenon of political 
Fauzi, Mudzakkir, Abdulrahim:Social

Conflict In Contestation Of Indonesia

Election

conflict about the process of election contestation experienced by research subjects (Moleong 2006). The presentation of data from this study uses a descriptive format intending to describe, summarize the sharing of conditions, various situations or various political phenomena that arise in a society that is running a democratic agenda (Bungin 2001). The researcher presents the results by describing the structural conflict clearly between the parties involved.

The determination of research subject is carried out utilizing purposive sampling, namely determining in advance the research subject with the assistance of the KPU's decision on the list of legislative candidates. Researchers also did snowball in seeking informant information because the problems of legislative candidates and the problems of political parties were relatively similar although there were also differences. Snowball makes it easy for researchers to get a lot of information with informants moving from one to the other easily.

Researchers make news information in a variety of print and electronic media to add and complement this research data. The news becomes information leading to the truth after there is a comparison of various news that is slightly different and clarification of other sources, then seated comparable so that conclusions can be drawn about the truth of information from media news and information on research subjects. Many electronic media that's being sourced, like Kompas TV, TV One and Metro TV. As for print media such as Jawa Pos, Tribun News Stand, Kompas and others.

Researchers used Paul Conn's conflict structure theory to analyze the phenomena of political party conflict and the conflicts of fellow legislative candidates. Conn's conflict theory is interesting as an instrument for analysis because the life of political party conflict as in the background of the presence of Conn's conflict structure theory can be divided into two conflict situations, first a win-lose conflict (zero-sum conflict) and a win-win conflict (non-zero- sum conflict). Both can lead to social life, although sometimes they bring destruction (Surbakti 2010).

The ideology of media is different to be compared with the ideology of social and religion. The ideology of media based on public opinion, It messages to influence and direct the masses (reader) and point of transferring the information as these ideologies( $\tilde{A}+a k m a k$ 2018). Democratic countries as in Indonesia, media 
have power, the free media is regarded as the "fourth estate" besides the legislative, executive and judiciary branches(Burak 2018).

The difference between field data, media information, and ideology. The three of which clash or are not related to information on conflict of nominating elections. These differences make it a challenge for researchers to be more careful in getting data, processing, and analysis.

\section{RESULTS AND DISCUSSION}

The implementation of the 2019 elections had many political records and democratic developments because at that time it was the first multi-party election held in comparison to the vice-presidential election. Elections held before 2019, namely in 2014, when separated between legislative and presidential elections, it was seen that the election organizers carried out a deliberative democratic agenda that was equally busy and complicated, although, in the end, it was able to carry out well (Nadir, Wardani 2019). In the 2019 elections, the election organizers were super complicated and busy. Moreover, it is added by its busyness in facing political party conflicts and conflicts of legislative candidates at the stage of preparing for the election, implementing and determining the elected legislative candidates.

The behavior of politicians and voters is different. Politicians hope to get public trust even though in the meantime it gets a negative note because promises and programs have not been implemented, while voters are interested in participating if hopes for candidates to build a better country (Fauzi 2019). The difference in perspective can lead to conflict between election contestants and the voting community. Conflicts between communities can occur if there are no differences in bridging choices, the parties to the conflict want to bring the best leaders to their regions.

Political party conflicts are conflicts that often attend elections every five years. At the beginning of the independence conflict due to different ideologies as described by Gertz about trichotomy (Burhani 2017). This is different than the current development, in which the quantity of political parties increases or decreases ahead of the democratic party because election regulations provide an opportunity to establish and register political parties as eligible participants. On this occasion, conflicts between fellow management in a political party often 
Fauzi, Mudzakkir, Abdulrahim:Social

Conflict In Contestation Of Indonesia

Election

occur because they want leadership power in a political party. Conflicts occur in some political parties, both political parties that already have an electoral threshold or political parties that have registered for the first time as political parties participating in elections.

The outbreak of political parties happened several times. The first conflict occurs when an elite political party has high human resources and has sufficient capital, then he has the potential to establish his political party if in the old political party is not given the confidence to lead a political party. This is as Surya Paloh's experience in establishing the Democratic National Party (P. Nasdem) after he failed to win the leadership of the Golongan Karya (P. Golkar) at the 8th National Conference (Munas) in 2009 because what was determined was Aburizal Bakrie as the winner of Munas. In contrast to the Reformed United Development Party (PPP) which subsequently turned into the Reform Star Party (PBR) is a fraction of the United Development Party after the conflict in 2003. There are many other examples, for example, the Sun Nation Party (PMB) which was established in 2006 is a fraction of the National Mandate Party (PAN) and others.

The second conflict stems from conflicts of fellow legislative candidates. This conflict is divided into three conflicts, namely the first conflict between legislative candidates in one political party, the second is a conflict between different legislative candidates by political parties based on the ideology or paradigm that is fought for, and thirdly conflicts between legislative candidates of different political parties due to being a jumping-off to the party other politics on the grounds of power interests.

The third phenomenon of the conflict is increasingly hardened in the 2019 elections. This is because the implementation of the democratic party provides more opportunities for politicians to have the courage to express their thoughts freely and to share their opinions.

Political party conflicts sometimes produce divisions within internal political parties, even the destruction and dissolution of political parties. If in one political party many smart people are human resources who raise political parties, but if they cannot manage it, the intelligence of the political party elites presents a conflict forever, this is the cause of political party's destruction after they grow up (Subekti 2017). There are other causes of conflict, for example, constitutional 
reform, the institutionalization of ideology and principles in a politic party (Yahaya 2019).

Legislative candidate conflicts in one political party are conflicts that can advance political parties if managed properly. Conversely, if it is not able to manage, it can make political parties unable to grow or even die. This is as happened in the Hanura Party, after internal party conflicts, he could not reach the electoral threshold in the 2019 elections. One reason is the dualism of leadership in the Hanura Party, although there may be other causes.

The second conflict between the different legislative candidates is different political parties, this is usually the one that ignited the ideology of political parties and the paradigm of national and state development. Ideology becomes the spirit in building political parties. The greatness of political parties is influenced by an attractive ideology and makes voters move as people who support the life and development of political party ideology.

The third conflict begins with the inconsistency of someone in the ideology and paradigm of political parties, when he does not fit into the leadership or differing views, then he chooses to get out of one political party and then into another political party. He ran as a candidate for the legislature of the political party he had just joined and usually he got a place because he had bargaining power with a variety of positive experiences before.

The conflicts often leave negative notes in the life of the nation and state, formerly friends become opponents, siblings turn into enemies, habits of helping friends turn into no matter the needs of friends. It's different than conflicts that occur in a political party.

There are twenty-one (21) legislative candidates of the House of Representatives going forward to become legislative candidates with changes in political parties, as the release of the Election Concerned Community Forum (FORMAPPI), which is illustrated, plus there are Nine (9) names that have not been read by the public (Anon 2018) in the following table: 
Fauzi, Mudzakkir, Abdulrahim:Social

Conflict In Contestation Of Indonesia

Election

Table 1

Candidates who move political parties

\begin{tabular}{|c|c|c|c|c|}
\hline No. & Name & $\begin{array}{c}\text { First Political } \\
\text { Party }\end{array}$ & $\begin{array}{c}\text { New } \\
\text { Political } \\
\text { Party }\end{array}$ & Information \\
\hline 01 & Mahardika Suprapto & P Nasdem & P Gerindra & Komisi X \\
\hline 02 & Arif S Suditomo & P Hanura & P Nasdem & Jabar 1 \\
\hline 03 & Fauzi H Amro & P Hanura & P Nasdem & SumSel 1 \\
\hline 04 & Rufinus Hutauruk & $\mathrm{P}$ hanura & P Nasdem & Sumatera II, Bali \\
\hline 05 & Dossy Iskandar P & P Hanura & P Nasdem & Jatim VIII \\
\hline 06 & Dadang Rusdiana & P Hanura & P Nasdem & Jabar II \\
\hline 07 & Okky Asokawati & PPP & P Nasdem & DKI Jakarta II \\
\hline 08 & Krisna Mukti & PKB & P Nasdem & Jabar X \\
\hline 09 & Sri Wulan & P Gerindra & P Nasdem & Jateng III \\
\hline 10 & Roberth Rouw & P Gerindra & P Nasdem & Papua \\
\hline 11 & Rita Zahara & P Gerindra & P Nasdem & Riau 1 \\
\hline 12 & Sjachrani Mataja & P Gerindra & P Nasdem & KalSel II \\
\hline 13 & Indira Chunda TIta & PAN & P Nasdem & SulSel 1 \\
\hline 14 & Epyardi Asda & PPP & PAN & Komisi II \\
\hline 15 & Venna Melinda & P Demokrat & P Nasdem & Jatim VI \\
\hline 16 & Mukhtar Tompo & P Hanura & PAN & SulSel II \\
\hline 17 & Frans Agung Mula P & P Hanura & P Nasdem & Lampung II \\
\hline 18 & Ammy Amalia F.S.. & PAN & P Nasdem & Jatim VIII \\
\hline 19 & Tina Nur Alam & PAN & P Nasdem & SulTeng \\
\hline 20 & Sarifuddin Sudding & P Hanura & PAN & SulTeng \\
\hline 21 & Achmad Dimyati N & PPP & PKS & DKI Jakarta III \\
\hline 22 & Siti Hediati Soeharto & P Golkar & P Berkarya & Yogyakarta \\
\hline 23 & Fandi Utomo & P Demokrat & PKB & Jatim 1 \\
\hline 24 & Lucky Hakim & PAN & P Nasdem & JaBar VI \\
\hline 25 & Deddy Gumelar & PDI P & PAN & Gagal Pilwali \\
\hline 26 & Krisna Mukti & PKB & P Nasdem & Jabar X \\
\hline 27 & Angel Lelga & PPP & Perindo & Jabar VII \\
\hline 28 & Riefian Fajarsyah & P Gerindra & PKB & Kalbar 1 \\
\hline 29 & Wanda Hamidah & PAN & P Nasdem & DPRD DKI \\
\hline 30 & Muhammad Farhan & PDI P & P Nasdem & Jabar 1 \\
\hline
\end{tabular}

Source: From various media and elite of party

Hanura Party has 16 parliamentary seats, that moved to another politic party as 8 legislative, this shows that P Hanura was not very attractive to the 2019 legislative candidates. According to CSIS (Central for Strategic and International Studies) that the move was due to, first the internal political party conflict, second new parties gave guarantees to the electoral district and serial number in the nomination of an election. 
The opinion of CSIS institutions that P. NasDem is a political party that facilitates legislative candidates to move, consists of 6 people from Hanura, 5 from P. Gerindra, 3 from P. Democrats, 2 from PKB, 2 from PAN, and 2 from PPP, the number of all candidates who moved as many as 20 politicians . In contrast, the Hanura party was the party that lost the most incumbent candidates because of moving nominations, including 6 people moving to NasDem and 1 candidate moving to PAN (Anon 2019).

The movement of politicians has made the political map change, both in terms of the nominating legislative candidates, the enthusiasm of political parties in the campaign and even the shifting of seats in the election results. The reality of the movement must be accepted because political parties cannot limit it, there is no regulation prohibiting it. Election contestation every five years is like a free battle, depending on how the rhythm of the political game is arranged so that the proposed political party or candidate can win.

No legislative candidate is interested in moving political parties or electoral districts, this is because they have been serving as members of the legislature (incumbent) who have served the people in that place. This service should have a positive effect as capital to move forward in five years in the next election period. Social facts show that he is in conflict with his political party so that there are two choices, first accepting the decision of a political party to be nominated wherever the place is or the second option, he chooses to leave the political party by entering other political parties so that he has the opportunity to advance again where he wants.

When conflicting in the form of a political party split or the transfer of political parties, the parties to the conflict seemed to be strong and strong. They feel on the right side and will win the election contestation. Emotions are the vanguard of this obstinacy, so they don't look difficult or sad. Friendship in one party for the past five years has been erased instantly without any shame or discomfort because political party life should be based on the ideology of political parties, not the interim interests of politicians.

The election results in a shift in the legislative seat between the conflicting parties. First, shifting the victory or winning votes of the people's choice, this is a political party whose legislative seats are reduced, on the contrary, there are more. Second, the shift of elected candidates in a political party occurs, this is because 
Fauzi, Mudzakkir, Abdulrahim:Social

Conflict In Contestation Of Indonesia

Election

of the effect of moving the electoral district, the incumbent is not able to do much in the new electoral district because voters and their confidants are in the old place.

Conflicts bring changes in election results. The conflict that is well managed then produces the greatness of political parties. It has a positive effect on increasing seats in parliament. This is in line with the application of the structural theory of conflict that was conceived by Paul Conn, because in Conn's idea of win-win (non-zero sum conflict) that the more conflicts, the political parties increasingly display the stronger human resources to respond to the problems of political parties.

This is different when using structural conflict win-lose (zero-sum conflict), then what happens is a greater conflict between political parties and between contesting politicians. Between conflicting political parties want to eliminate each other's, political opponents. Conflicts between legislative candidates will also finish off their opponents until they cannot rise again in politics.

Conn based his conflicting thinking on struggling for existing capital as workers in conflict to achieve a better life. Seizure of capital has the effect of bringing one's enthusiasm and igniting emotions to reach the conflict if it compromises it results in a win-win between the conflicting parties. In contrast, if you use structural win-lose, it will finish off the losing party at the root.

The conflict Conn feels synergized with Foucault's thoughts about power. (Birsyada 2016). Power is present because of the product of the discourse of the parties to the conflict, as well as readers of the history of conflict over the discourse of conflict that is being understood by the general public.

Election conflicts before the 2019 elections often occur, one of which was in the 2017 DKI Jakarta elections where Anies Baswedan-Sandiaga Uno was able to win. The conflict occurred after Anies Baswedan was dismissed from the minister of national education in the Jokowi-Jusuf Kalla government cabinet. The conflict brought Baswedan's enthusiasm to contest in the DKI Regional Election. He presented a direct approach strategy to the "groundwell" community as in the 2012 Jakarta Election Jokowi used "blusukan". If Baswedan is not dismissed by 
Jokowi from his Cabinet, the possibility of winning the Jakarta Regional Election for Baswedan is unlikely to occur (Damayanti 2019).

Conflict of win and lose is an atmosphere of conflict that is antagonistic between the parties to the conflict. In this situation a compromise is impossible or between parties to the conflict can accept a decision. The winner will take all the wins without giving to the losing party to contest. This conflict is long-lived because there is no sense of togetherness to build a society and a nation. A person's intelligence and greatness have no place to be respected if they lose in political contestation.

Win-win conflict is a situation of conflict between parties involved in a conflict there is an opportunity for compromise in the common interest. Here it is usually not about principles that can work together after conflict occurs.

The 2019 election of political conflict can be divided into two conflict structures. both have an explanation as to the political process and political outcome. Some parties can qualify smoothly without being threatened by their participation in the coming five years, on the other hand, there are political parties that are threatened that they cannot participate in the 2014 elections unless they have to register their political parties from zero because they did not pass the electoral threshold.

Figure 1

2019 Presidential and Vice-President Election2019 Presidential and VicePresidential Election

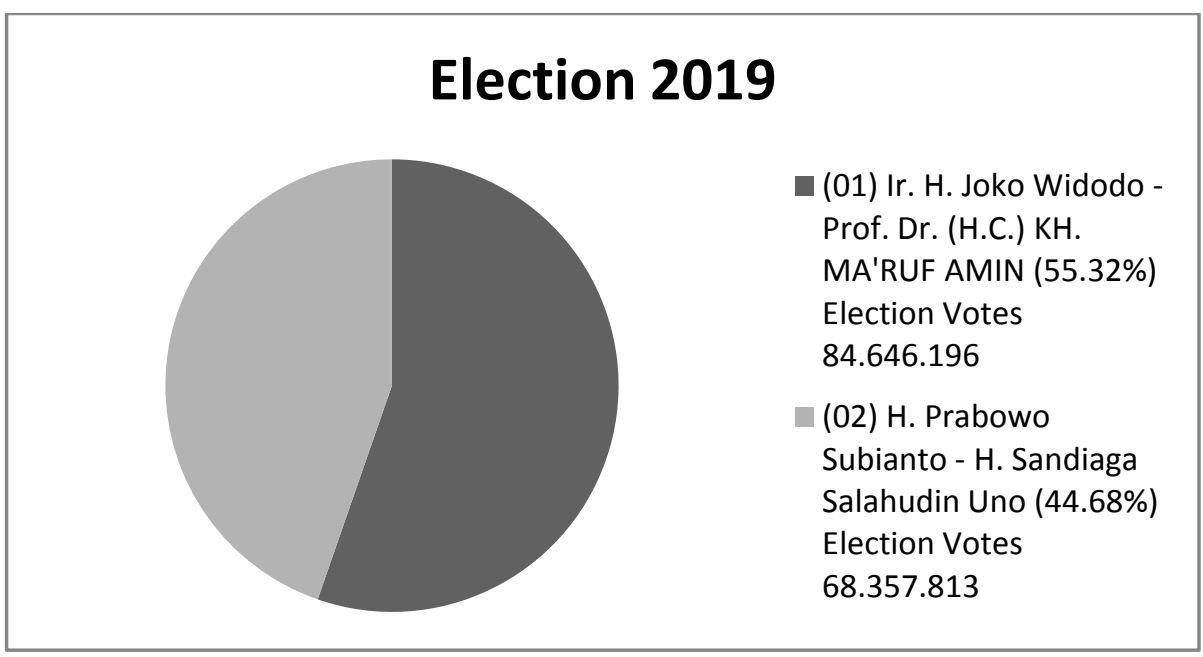

Source: KPU RI 
Results In the results figure Joko Widodo \& Ma'ruf Amin's victory could not achieve a total victory (KPU RI 2019). The victory is very thin, so the winner thinks again if he will take all the power for himself, in the thought of Conn, which displays the structure of conflict, win and lose.

This is different if we pay attention to the legislative elections which are held at the same time as the 2019 presidential and vice presidential elections. The results are as follows:

Table 2

2019 Legislative Election Results

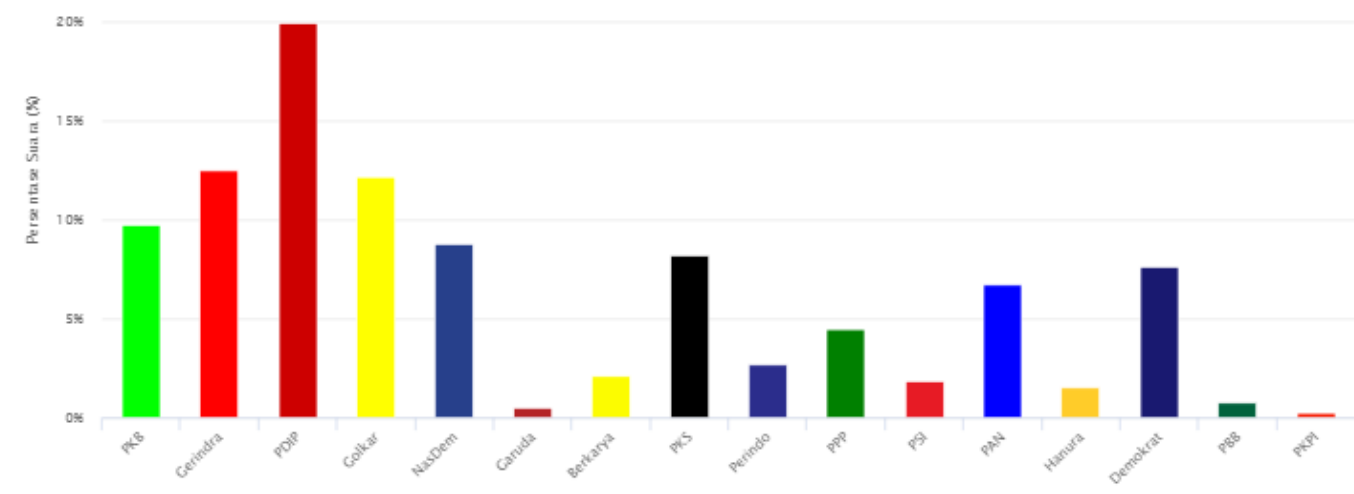

Source: From KPU RI

The data in Table 2 can be explained that some political parties are unable to meet the electoral threshold of 4 percent, finally must accept the decision of the rules of the game in the election as in Law No. 7 of 2017. First, the acquisition of political parties at the national level will not be sworn in as a legislative member despite having a few seats. Second, in the 2024 elections, political parties must register as political parties and as participants in the election from zero.

Conflict sociology sees political conflicts as common in the political process. Conflict can produce positive things, on the contrary, be the cause of corruption in government leadership (Fauzi 2018). Victory in political contestation sometimes leaves some problems. For example, when political capital is high, then he leaves debt so that after being elected the mindset is to return debt loans using his power, even though this does not happen to all members of the legislature. This has resulted in opportunities to corrupt the country's finances. 
The conflict has logical consequences for the management of political parties. Politicians who have plans to move forward to become candidates for the legislature then immediately seek a solution to the conflict, both conflicts that occur between political parties or conflicts within one political party.

Some alternative places for escaping the management of political parties and politicians are: first is a political party that can provide a place to be creative in contestation. It is based that the life of political parties must be democratic, there is no restraint in expressing political aspirations. There are some bad examples in the practice of democracy as in the previous picture. These political parties still get the same gains as in the previous elections, even more. The reason is that politicians and legislative candidates work full time, there is no pressure in politics. If it is not suitable, someone may leave the political party, but it is usually unlikely that the legislative candidate, especially the incumbent, will leave the political party. This is the case with the P Golkar, P Gerindra and PDI Perjuangan parties.

Second, security guarantees in running for legislative candidates. The most feared of a legislative candidate is being eliminated when competing in internal political parties. Internal political party competition is tougher compared to its external, when there is a guarantee the legislative candidate feels comfortable in it, so he fights for real until he wins, which is re-elected as a member of the legislature. This brought the greatness of the voice of political parties.

Third, Chance to be re-elected. Legislative candidates when they intend to move forward again and have pledged as contestants, the main goal is to be elected. The calculation of legislative candidates puts the opportunity as the main thing, by basing on the votes of political parties in the previous election period and calculating the campaign branding in the elections that will be held.

These three categories of places where political parties escape are the main standard legislative candidates will fight in the electoral competition. The result is that many political parties have succeeded in matching the 2014 elections, or at least passing the electoral threshold, for example, PDI Perjuangan, P Golkar, PKB, P Gerindra, P Nasdem, PAN and PKS.

Political parties do not have three categories, so they do not qualify for the electoral treshold. He is P Hanura, who during the election period was full of conflicts in internal political parties until dualism of leadership occurred until 
Fauzi, Mudzakkir, Abdulrahim:Social

Conflict In Contestation Of Indonesia

Election

there was mutual firing or did not recognize the existence of the opposite management. This affects the people as voters, that is, their aspirations are tossed about.

There is one group that does not have three categories, but they still have a big name before so they can enter the electoral threshold. Political parties included in this group are the P. Democratic Party and the PPP. P Democrats can stay afloat because in the two previous elections the election had triumphed and had a president for two consecutive periods. PPP also survived because for 32 years the New Order was an opposition party so that the remnants of public trust were still enough to get the electoral threshold.

Based on the purpose of political conflict, he as a vehicle to obtain sources of income and maintain it. When associated with contestation, winning in contestation will be at stake with a different attitude from political opponents. This is more exciting if the purpose of the conflict is to maintain political power as illustrated in the 2019 election, namely all political parties to the conflict.

Political dynamics in elections are interesting to be the subject of research because political life in Indonesia is dynamic, this is because Indonesia is a developing country and is still searching for a democratic identity. The Pancasila democracy which is used as a political guideline still has diverse acceptance by politicians.

Political conflict is normal in the process of contestation because every politician has the awareness to win the contestation. Awareness to be a winner becomes positive if it is together with regulations that provide justice, equality, and togetherness for all eligible participants without any discrimination.

Views of the conflict as in the legislative elections, also occur between presidential candidates to win sympathy occurs, they present an unusual figure. They show various strengths to gain sympathy as shown by Joko Widodo and Prabowo Subianto as presidential candidates (Panuju 2019). This resulted in the presidential and vice presidential elections being described as enmity between two pairs of candidates, even though they were only contesting for the sake of a better national and state leadership within the next five years.

The appearance of election conflicts becomes attractive when the election administrators carry out their duties as stipulated in the election regulations. In the 
2019 elections based on Law no 17 of 2017 with the maximum implementation of regulations starting from the KPU RI (central) to the KPPS (the lowest) (Pandiangan 2019). The neutrality and professionalism of the election organizers is a guarantee against the conflict of the election contestation going well, to produce leaders and representatives of the people who are strong and receive aspiration.

The answer to this study is different from the previous research, illustrated in the conflict of the legislative election contestation process. Unhealthy competition dominates the behavior of politicians so that conflicts should bring improvements to the lives of political parties, but on the contrary, it hurts the people, for example, firing one another management. The intrigued each other to have a negative impact, which eventually resulted in some political parties participating in the 2019 election not passing the electoral threshold even though he had quite a long experience of being an election participant in the previous period.

The direct impact on legislative candidates who have political parties is the failure of legislative candidates from the incumbent element, the failure to become members of the legislature, then further away from political parties that have raised the politician.

\section{CONCLUSION}

Political party conflict in contestation is the dynamics of the political world. It can lead to a positive direction if the conflict is interpreted by the process of political development with a conflict of ideas between the conflict. It becomes negative when politicians are not ready to conflict, or conflict which results in hostility between political parties or internal political divisions that result in the failure of political parties to electoral treshold. Based on the results of the 2019 elections, conflicts between political parties only result in legislative candidates moving to other political parties, the choice of which is determined by each power of the legislative candidate, while the strength of political parties and ideologies is very small. Whereas internal political party conflicts affect the potential candidates running when they are not allowed to go back to using the electoral area of the original political party. The structure of Paul Conn's conflict becomes a knife of analysis that has an alternative between a win and loses (zero-sum 
Fauzi, Mudzakkir, Abdulrahim:Social

Conflict In Contestation Of Indonesia

Election

conflict) and win-win conflict (non-zero-sum conflict) so that the leaders of political parties choose according to the way of life of political parties.

\section{REFERENCES}

Ã takmak, Fatma. 2018. "The Role of Ideology in Political Communication and Media." The Journal of Social Sciences Research 4(12):813-19, 12-2018.

Anon. 2018. "Para Caleg Petahana Yang Pindah Partai Pada Pemilu Legislatif 2019." https://nasional.kompas.com/read/2018.

Anon. 2019. "Caleg Petahana Pilih Pindah-Partai Nasdem Jadi Tujuan Favorit." Https://news.detik.com/berita.

Birsyada, Muhammad Iqbal. 2016. "Legitimasi Kekuasaan Atas Sejarah Keruntuhan Kerajaan Majapahit Dalam Wacana Foucoult.” Walisongo: Jurnal Penelitian Sosial Keagamaan 24(2):311-32. Retrieved (https://ejournal.unisba.ac.id/index.php/mimbar/article/view/3994/pdf).

Bungin, Burhan. 2001. Metodologi Penelitian Sosial. Surabaya: Airlangga University Press.

Burak, Begüm. 2018. "Media Discourse, Ideology and Print Media in Turkey." Electronic Journal of New Media 2(2):53-62.

Burhani, Ahmad Najib. 2017. "Geetz's Trichotomy of Abangan, Santri, And Priyayi Controversy and Continuity." Journal of Indonesian Islam 11(2):329-50.

Retrieved (http://jiis.uinsby.ac.id/index.php/JIIs/article/view/556/pdf_14).

Damayanti, Novita, and Radja Erland Hamzah. 2019. " $\hat{a} €^{\mathrm{TM}}$ The Groundswell $\hat{a} €^{\mathrm{TM}}$ Political Campaign Strategy of Anies-Sandi in the 2017 DKI Jakarta Governor Election." 35(1):28-37. Retrieved

(https://ejournal.unisba.ac.id/index.php/mimbar/article/view/3994/pdf).

Fauzi, Agus Machfud. 2018. Politik Kebijakan Pemberantasan Korupsi. 1st ed. edited by R. H. Sadewo, FX Sri \& Listiyani. Surabaya: UNESA University Press.

Fauzi, Agus Machfud. 2019. "Perilaku Pemilih Menjelang Pemilu 2019.” Journal of Islamic Civilization 1(1):40-48.

Retrieved (http://journal2.unusa.ac.id/index.php/JIC/article/view/918).

Fauzi AM, A Sudrajat 1, A.Affandi 1.and A.Raditya 1. 1. 2018. "Maintaining Identity Political Culture In Indonesia." Pp. 1-6 in, vol. 2. Retrieved (https://iopscience.iop.org/article/10.1088/1742-6596/953/1/012185/meta). 
Fuad, A. B.Barrul. 2014. "Political Identity and Election in Indonesian Democracy: A Case Study in Karang Pandan Village - Malang, Indonesia." Procedia Environmental Sciences 20:477-85.

Retrieved (http://dx.doi.org/10.1016/j.proenv.2014.03.060).

Hidayat, Medhy Aginta. 2017. "Ibadat, The Body And Identity: Islamic Rituals

And The Construction of Muslim Identity." The Journal of Society \& Media 1(2):1-17.

Retrieved(https://journal.unesa.ac.id/index.php/jsm/article/view/1729/1167).

Kamarudin. 2013. "Konflik Internal Partai Politik: Studi Kasus Partai Kebangkitan Bangsa Intra-Party Conflict:" Jurnal Penelitian Politik 10(1):29-39. Retrieved

(http://ejournal.politik.lipi.go.id/index.php/jpp/article/view/216/92).

KPU RI. 2019. "Hasil Hitung Suara Pemilu Presiden \& Wakil Presiden RI 2019." Kpu.go.id. Retrieved (https://pemilu2019.kpu.go.id/\#/ppwp/hitung-suara/).

Moleong, Lexi J. 2006. Metodologi Penelitian Kualitatif. Bandung: PT Remaja Rosadakarya.

Muzaki, Muzaki. 2018. "Partisipasi Tokoh Masyarakat Dalam Toleransi Umat Beragama." KOMUNIKA: Jurnal Dakwah Dan Komunikasi 4(1):160-77.

Nadir; Win Yuli Wardani. 2019. "Membangun Pendidikan Politik Dalam Fatsun Demokrasi Pancasila dan Deliberative." The Journal of Society \& Media 3(1):126-41.

Retrieved

(https://journal.unesa.ac.id/index.php/jsm/article/view/4169).

Pandiangan, Andreas. 2019. "Kelompok Penyelenggara Pemunguta Suara (KPPS) Pemilu 2019: Tanggungjawab dan Beban Kerja." The Journal of Society \& Media 3(1):17-34.

Retrieved (https://journal.unesa.ac.id/index.php/jsm/article/view/4229).

Panuju, Redi. 2019. "The Comparison of Jokowi and Prabowo Subianto Exposed on YouTube." Prabowo Subianto Exposed on YouTube 22(3):245-58. Retrieved (https://jurnal.ugm.ac.id/jsp/article/view/33172/pdf).

Romli, Lili. 2017. "Koalisi dan Konflik Internal Partai Politik pada Era Reformasi Coalition and Internal Party Conflicts of Reform Era in Indonesia." Politica 8(2):95-118.

Retrieved (https://jurnal.dpr.go.id/index.php/politica/article/view/1138).

Subekti, Valina Singka. 2017. "Prolonged Elite Conflict and the Destruction of the Indonesian Islamic Union Party (PSII).” Studia Islamika 24(2):295-335. Retrieved (http://journal.uinjkt.ac.id/index.php/studiaislamika/article/view/4580).

Surbakti, Ramlan. 2010. Memahami Ilmu Politik. Jakarta: PT Gramedia 
Fauzi, Mudzakkir, Abdulrahim:Social

Conflict In Contestation Of Indonesia

Election

Widiasarana Indonesia.

Yahaya, Muhammad Aminu. 2019. "The Changing Nature and Pattern of IntraParty Conflict in Nigeria's Fourth Republic: Critical Assessment of All Progressives Congress.” Malaysian Journal of Society and Space 15(2):5768. 